\title{
QUALITY ENHANCEMENT OF TOMATOES (Lycopersicum esculentum Mill.) USING GIBBERELLIC ACID (GA) FROM VARIOUS PLANT MATERIALS
}

\author{
N.N.A. Mayadewi ${ }^{1 *}$ \& I.N.G. Astawa ${ }^{1}$ \\ ${ }^{1}$ Departement of Agroecotechnology, Faculty of Agriculture, Udayana University, Bali \\ *Corresponding author: arimayadewi@unud.ac.id
}

\begin{abstract}
Tomato (Lycopersicum esculentum Mill.) is a fruit with many benefits. Plant growth regulators (PGRs) prove effective in improving the quality and production of tomatoes. Gibberellic Acid/GA is a PGR that stimulates the process of flowering, parthenocarpy, and carbohydrate mobilization during germination and influences other plant physiological aspects. However, because synthetic GA is costly, numerous natural ingredients have been proposed as its source, for example, bamboo shoots, vegetable ferns, corns, and shallots that can improve the quality of tomatoes. This study aimed to determine the role of natural GA from various plant extracts on the quality of tomatoes, providing recommendations for the best extract to improve the quality of tomatoes. It was conducted in the experimental garden at the Agronomy and Horticulture Laboratory, Physiology Laboratory of the Faculty of Agriculture, and Food Analysis Laboratory of the Faculty of Agricultural Technology, Udayana University. This research was compiled using a Randomized Group Design consisting of one factor, i.e., the type of natural extract with five settings and four repetitions. The tomato plant treatments were $\mathrm{E} 0=$ no extract sprayed, $\mathrm{BE}=$ sprayed with bamboo shoot extract, $\mathrm{VE}=$ vegetable fern extract, $\mathrm{OE}=$ onion extract, and $\mathrm{CE}=$ corn extract. The results showed that gibberellins from natural ingredients significantly affected fruit diameter, fruit thickness, and total sugar content of tomatoes. The best tomatoes were obtained by applying onion extract as a source of natural gibberellins.
\end{abstract}

Keywords: fruit quality, natural gibberellins, tomato

\section{INTRODUCTION}

Tomatoes

(Lycopersicum

esculentum Mill.) are fruits with many benefits. They can be eaten fresh and raw, added as a flavoring agent to various dishes like soups and chili sauce, and used as an ingredient in food and beverage industries such as juices, processed juices, tomato sauces, concentrates, puree, and porridge. In addition, food providing a fairly complete vitamin content can help prevent diseases like cancers. As food, tomatoes are classified as plants rich in nutrition, including thiamin, protein, fat, carbohydrates, fiber, and calcium (Bambang, 2008).

Most of the tomatoes used by the community are those of variants with more pulp and fewer seeds. Efforts can be made to improve the quality and production of tomatoes with plant growth regulators (PGR). One type of PGR is 
gibberellins. Gibberellins or gibberellic acid (GA) can stimulate flowering, irradiation, parthenocarpy, carbohydrate mobilization during germination, and other physiological aspects (Rai and Wiraatmaja, 2010). However, because synthetic GA is costly, natural ingredients have been proposed as an alternative source of GA. Besides, natural PGR from organic matter is safer to use, environmentally friendly, easy to obtain, and inexpensive (Isrianto, 2017). Many plant species are natural sources of GA, namely rice, corns, shallots, spinach shoots, and ferns (Martin, 2016). Astawa et al. (2016) found that $100 \%$ bamboo shoot extract most substantially increases the sweet taste of Balinese grapes compared with controls. In addition, Isnaini et al. (2016) confirmed that natural GA sourced from bamboo extracts improves the quality of Balinese grapes.

GA is a growth regulator required in fruit plants to increase growth and yield, both in quality and quality. GA effectively improves the quality of peaches, strawberries (Ahadi et al., 2013), and palm dates (Awad and Qurazhi, 2012). Factoring in its effects on fruit plants, this research scrutinized whether or not adding GA to the tomato plant treatment regime improves the quality of the fruits.

\section{MATERIALS AND METHODS}

The research was carried out in the Experimental Garden Greenhouse at the Agronomy and Horticulture Laboratory of the Faculty of Agriculture, Udayana University, and the Food Analysis Laboratory at the Faculty of Agricultural Technology, Udayana University. The study was conducted from April to October 2019.

\section{Materials}

Materials used in the study were tomato seeds, compost, soil, husks, NPK fertilizer, the shoots of betung bamboo (Dendrocalamus asper Backer ex Heyne), vegetable ferns, shallots, corns, EM4, sugar, and water. The tools used were $40 \times 60 \mathrm{~cm}$ polybags, markers, raffia strings, shovels, cutting knives, cutting boards, basins, blenders, jars, plastics, rubber bands, filtering devices, sprayers, scales, rulers, stationery, plastic bags, labels, scissors, hand refractometers, and baskets.

\section{Methods}

The study employed a Randomized Complete Block Design (RCBD) with one factor, namely spraying the tomato flower buds with extracts of natural ingredients that contain GA. This design comprised five treatments with four repetitions, resulting in 20 experimental units. The five treatments were: 


$$
\begin{array}{ll}
\mathrm{E} 0 & =\text { no extract } \\
\mathrm{BE} & =\text { bamboo shoot extract } \\
\mathrm{CE} & =\text { corn extract } \\
\mathrm{VE} & =\text { vegetable fern extract } \\
\mathrm{OE} & =\text { onion extract }
\end{array}
$$

The tomatoes were planted from seeds. After two leaves were formed (21 days after sowing, DAS), the seedlings were ready to be transplanted. The growing media was a mix of soil, compost, and husks in a ratio of 1:2: 1 , which was then put into 20 polybags with a diameter of $40 \mathrm{~cm}$. Only seedlings showing uniform growth were transplanted and observed. NPK was applied three times, i.e., at 14,24 , and 35 days after transplanting (DAT).

The natural GA was prepared following the method used by Da Silva et al. (2013), namely fermenting the solid form of selected natural ingredients (pulp) with EM4 using the technique used by Kebun Musangking (2014). The ingredient (200 g) was first cut into a small size and then blended until a pulp was formed. Afterward, the pulp was placed in a jar, mixed with 1 liter of water, $200 \mathrm{~g}$ of sugar, and $50 \mathrm{ml}$ of EM4, then stirred until evenly distributed. The jar containing the mixture was covered with plastic, tied with a rubber band, and left for 15 days in a shady place to create proper fermentation. The purpose of fermentation was to decompose gibberellins contained in bamboo shoots. After settling for 15 days, the fermented mixture was filtered, the pulp was removed, and the derived liquid was put into a jar; the liquid is called natural GA extract.

The flower buds were thoroughly sprayed once before blooming or at \pm 45 DAT. This spraying was according to the experimental design made. Afterward, at the age of \pm 65 DAT, the tomatoes whose green color had turned yellowish were harvested by manual picking. The yields were put in labeled plastic bags and then brought to the Agronomy and Horticulture Laboratory for observation.

The variables observed consisted of weight per fruit $(\mathrm{g})$, weight of seeds per fruit (g), number of seeds per fruit (pcs), fruit diameter $(\mathrm{cm})$, fruit thickness $(\mathrm{cm})$, vitamin C content (mg), and total sugar content (\%).

\section{RESULTS AND DISCUSSION}

The tomato plant treatment with natural GA exhibited a significant effect on fruit diameter $(\mathrm{cm})$, fruit thickness $(\mathrm{cm})$, and total sugar content (\%) in the observed tomatoes. However, it insignificantly influenced weight per fruit $(\mathrm{g})$, seed weight per fruit (g), number of seeds per fruit (pcs), and vitamin $\mathrm{C}$ content (mg). The effects of GA from different natural extracts on the 
observed variables and their significance can be seen in Table 1.

The different types of natural GA applied to the tomato plants showed insignificant differences in weight per fruit, seed weight per fruit, and number of seeds per fruit. However, in general, the bamboo shoot extract (BE), corn extract (CE), vegetable fern extract (VE), and onion extract (OE) were able to increase the weight per fruit by $18.77 \%, 17.82 \%$, $23.96 \%$, and $23.83 \%$, respectively, compared with the control (E0). It was found that applying natural GA to flower buds when the flowers had not bloomed generally can reduce the weight and number of seeds per fruit, although not statistically significant (Table 2). The corn extract (CE) produced the lowest weight and number of seeds per fruit, i.e., $0.10 \mathrm{~g}$ and 43.60 pcs.

Table 1. The significance of the effect of GA from natural extracts on the observed variables

\begin{tabular}{clc}
\hline No & \multicolumn{1}{c}{ Variable } & Significance \\
\hline 1 & Weight per fruit & ns \\
2 & Weight of seeds per fruit & ns \\
3 & Number of seeds per fruit & ns \\
4 & Diameter of fruit & \\
5 & Fruit thickness & $* *$ \\
6 & Vitamin C content & ns \\
7 & Total sugar content & \\
\hline
\end{tabular}

Notes: ns= not significant,

Table 2. Effects of natural GA on weight per fruit (g), weight of seeds per fruit (g), and number of seeds per fruit (pcs).

\begin{tabular}{lccc}
\hline \multicolumn{1}{c}{ Treatment } & $\begin{array}{c}\text { Weight per } \\
\text { fruit }(\mathrm{g})\end{array}$ & $\begin{array}{c}\text { Weight of seeds } \\
\text { per fruit }(\mathrm{g})\end{array}$ & $\begin{array}{c}\text { Number of seeds } \\
\text { per fruit }(\mathrm{pcs})\end{array}$ \\
\hline Control (E0) & $16.83 \mathrm{a}$ & $0.16 \mathrm{a}$ & $56.60 \mathrm{a}$ \\
Bamboo Shoot Extract (BE) & $20.72 \mathrm{a}$ & $0.12 \mathrm{a}$ & $45.60 \mathrm{a}$ \\
Corn Extract (CE) & $20.48 \mathrm{a}$ & $0.10 \mathrm{a}$ & $43.60 \mathrm{a}$ \\
Vegetable Fern Extract (VE) & $21.96 \mathrm{a}$ & $0.13 \mathrm{a}$ & $49.60 \mathrm{a}$ \\
Onion Extract (OE) & $22.12 \mathrm{a}$ & $0.12 \mathrm{a}$ & $51.20 \mathrm{a}$
\end{tabular}

BNT 5\% ns ns ns

Notes: Figures followed by the same letter show no significant difference in the LSD test of $5 \%$ level; $\mathrm{ns}=$ not significant 
In addition, spraying flower buds with GA from various natural extracts had significantly different effects on fruit diameter and fruit thickness (Table 3). The onion extract (OE) produced the largest fruit diameter of $3.34 \mathrm{~cm}$, which is significantly different from the control but not from other treatments. OE spray also led to the largest fruit thickness, i.e., $0.58 \mathrm{~cm}$, which is significantly different from other treatments, except the corn extract (CE).

Table 3. Effects of natural GA on fruit diameter $(\mathrm{cm})$ and fruit thickness $(\mathrm{cm})$

\begin{tabular}{lcc}
\hline \multicolumn{1}{c}{ Treatment } & Fruit Diameter $(\mathrm{cm})$ & Fruit Thickness $(\mathrm{cm})$ \\
\hline Control (E0) & 2.98 & 0.42 \\
Bamboo Shoot Extract (BE) & 3.29 & 0.50 \\
Corn Extract (CE) & 3.11 & 0.56 \\
Vegetable Fern Extract (VE) & 3.27 & 0.52 \\
Onion Extract (OE) & 3.34 & 0.58 \\
\hline BNT 5\% & 0.25 & 0.051 \\
\hline
\end{tabular}

However, the effects of various natural GA sprays on the vitamin $\mathrm{C}$ content of the harvested tomatoes were not significantly different. The highest vitamin C content, $59.64 \mathrm{mg}$, was obtained from the vegetable fern extract (VE), whereas the lowest was from the control (E0), $55.42 \mathrm{mg}$. The total sugar content was the highest in tomatoes whose flower buds received onion extract (OE) spray, i.e., $4.15 \%$ or significantly different from other treatments (Table 4).

Table 4. Effects of natural GA on vitamin C content (mg) and total sugar (\%)

\begin{tabular}{lcc}
\hline \multicolumn{1}{c}{ Treatment } & Vitamin C (mg) & Total sugar (\%) \\
\hline Control (E0) & 55.42 & 1.75 \\
Bamboo Shoot Extract (BE) & 58.45 & 1.73 \\
Corn Extract (CE) & 57.93 & 2.42 \\
Vegetable Fern Extract (VE) & 59.64 & 2.20 \\
Onion Extract (OE) & 57.73 & 4.15 \\
\hline BNT 5\% & ns & 1.39 \\
\hline
\end{tabular}


Fruit quality is a critical indicator in meeting market demands. Efforts to increase the quality of tomatoes by giving natural GA from a variety of plants can be evaluated from the increase in fruit diameter, fruit flesh thickness, and total sugar content. Although the various types of natural GA applied did not show significant differences in weight per fruit, seed weight per fruit, and the number of seeds per fruit, the bamboo shoot extract (BE), corn extract (CE), vegetable fern extract (VFE), and onion extract $(\mathrm{OE})$ can generally increase weight per fruit and vitamin $\mathrm{C}$ content and reduce weight and number of seeds per fruit. The increase in fruit weight produced by the natural GA-treated plants is affected by an increase in the diameter and thickness of fruit flesh (Permatasari et al., 2016).

In addition, natural GA decreases the weight and number of seeds per fruit because of the ability of gibberellins to inhibit the development of embryos in the seeds. Consequently, the seeds are not perfectly formed, resulting in small and soft seeds (Wulandari et al., 2014).

\section{CONCLUSION}

1. Plant treatment with natural GA from various plant extracts significantly affects fruit diameter, fruit thickness, and total sugar content of tomatoes.

2. In the effort to improve the quality of tomatoes, onion extract gives the best results, as evident from the largest fruit diameter, fruit thickness, and total sugar content.

\section{ACKNOWLEDGMENTS}

The authors would like to thank the Rector and Vice Rector, the head and staff of LPPM, and the Dean of the Faculty of Agriculture at Udayana University for funding and facilitating the research process, from proposal writing to research implementation and research results dissemination.

\section{REFERENCES}

Astawa ING, R Dwiyani, NNA Mayadewi, IM Sukewijaya, NLM Pradnyawati. 2015. Perbaikan Kualitas Buah Anggur Bali (Vitis vinifera var. Alphonso lavallee) melalui Aplikasi GA3 Sebelum Bunga Mekar. Agrotrop 5 (1): 37-41.

Astawa ING, R Dwiyani, NNA Mayadewi, IM Sukewijaya, 2016. Aplikasi Asam Giberelin (GA) Alami dari Beberapa Jenis Tumbuhan Untuk Meningkatkan Mutu Buah Anggur Bali (Vitis vinifera $l$. var. Alphonso Lavallee)

Awad MA \& AD Al-Qurashi. 2012. Gibberellic acid spray and bunch bagging increase bunch weight and improve fruit quality of 
'Barhee' date palm under hot arid conditions. Scientia Horticulturae 138: $96-100$

Azadi Z, M Jafarpour, AR Golparvar, \& A Mohammadkhani. 2013. Effect of GA3 Application on Fruit Yield, Flowering and Vegetative Characteristics on Early Yield of Strawberry cv. Gaviola. Int. J. Agric. and Crop Sci. 5 (15): 1716 1718.

Cahyono, Bambang. 2008. Tomat Usaha Tani dan Penanganan Pasca Panen. Kanisius. Yogyakarta.

Casanova L, R Casanova, A Moret, \& M Agusti. 2009. The Application of Gibberellic Acid Increased Berry Size of 'Emperatriz' Seedless Grape. Span.J.Agric. Res. 7 (4): 919-927

Cirami RM, EJ Cameron, \& PR Hedberg. 1992. Special Culture Methods for Tablegrapes on_Coombe BG and PR Dry. (Eds) Viticulture vol.2 Practices. Pp 279-327

Da Silva, André Luís Lopes, Cristine Rodrigues, Jefferson Da Luz Costa, Marília Pereira Machado, et al. 2013. Gibberellic Acid Fermented Extract Obtained by Solid-State Fermentation Using
Citric Pulp by Fusarium moniliforme: Influence on Lavandula angustifolia Mill., Cultivated In Vitro. Pak. J. Bot. 45 (6): 2057-2064

Dagara A, A Wekstera, H Fiedmana, \& S Luriea. 2012. Gibberellic Acid (GA3) Application at the End of Pit Ripening: Effect on Ripening and Storage of Two Harvest of 'September Snow' Peach. Scientia Hort. 140: 125-130.

Herry Tugiyono. 2001. Bertanam Tomat. Penebar Swadaya. Jakarta https://books.google.co.id/books?id =tXMAOrr27bMC\&pg=PA5\&dq= klasifikasi+tanaman+tomat. page 7-8 (Accessed on December 18, 2018).

Rai. N., Wiraatmaja. W. 2010. Zat Pengatur Tumbuh Tanaman. Page 34-54.

Wulandari, D.C., Y.S. Rahayu, dan E. Ratnasari. 2014. Pengaruh Pemberian Hormon Giberelin terhadap Pertumbuhan Buah secara Partenokarpi pada Tanaman Mentimun Varietas Mercy. Jurnal LenteraBio 3(1) January 2014: 27-32. ISSN 22523979 